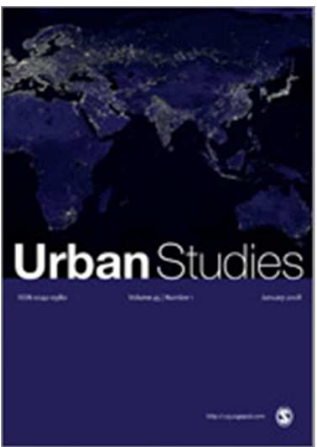

\title{
Victims of their own (definition of) success: urban discourse and expert knowledge production in the Liveable City
}

\begin{tabular}{|r|l|}
\hline Journal: & Urban Studies \\
\hline Manuscript ID & CUS-922-17-10.R2 \\
\hline $\begin{array}{r}\text { Manuscript Type: } \\
\text { keyword from the following list } \\
\text { that best describes the } \\
\text { discipline used in your paper.: }\end{array}$ & Pobates Paper \\
\hline $\begin{array}{r}\text { World Region: Please select } \\
\text { the region(s) that best reflect } \\
\text { the focus of your paper. } \\
\text { Names of individual countries, } \\
\text { cities \& economic groupings } \\
\text { should appear in the title } \\
\text { where appropriate.: }\end{array}$ & \\
\hline $\begin{array}{r}\text { Major Topic: Please identify up } \\
\text { to } 5 \text { topics that best identify } \\
\text { the subject of your article.: }\end{array}$ & Local Government, Place Branding, Policy, Politics \\
\hline $\begin{array}{r}\text { You may add up to } 2 \text { further } \\
\text { relevant keywords of your } \\
\text { choosing below:: }\end{array}$ & Liveability, Knowledge production \\
\hline
\end{tabular}

\section{SCHOLARONE \\ Manuscripts}




\title{
Victims of their own (definition of) success: urban discourse and expert knowledge production in the Liveable City
}

\begin{abstract}
The notion of 'liveability' has endured for over fifty years within policy discourses, shaping urban strategy and planning across the world. This Debates paper examines the current state of liveability discourse. Liveability is unpacked to consider the rhetorical work that it does to frame urban problems, select and order concepts, and build narratives that shape policy action. Liveability discourse has a dual role: it defines normative goals for a city and also reifies and demands particular forms of expert knowledge to justify and maintain its discursive power. This power is created by connecting the vague rhetoric of the 'liveable city' to expertise represented in liveability rankings and indicators.

The experiences of apparently 'liveable' cities show how liveability discourse creates a representation of the city that is in contrast to the experience of many residents. The use of aggregate metrics and reliance on indices generated from undisclosed data sources and 'expert judgement', obscures the differentiated quality of life and everyday experience for urban populations. Therefore, liveability discourse has exerted and maintained stronger discursive power to undermine urban livelihoods than to improve them, due to the phenomena and qualities that it conceals. Liveability's distinct type of discursive power must be recognised and mobilised to support a counter-narrative that reconnects urban policy with everyday urban life.
\end{abstract}

\section{Keywords}

Liveability, discourse, knowledge production, policy mobilities, urban governance 


\section{Introduction}

"People laugh, when they are stuck in hours of traffic congestion, about being the most liveable city. They laugh when they see that might be our slogan, but we are the fourth most unaffordable city to live in."

(Goff, P. cited in New Zealand Herald 2016)

This quote from the incumbent mayor of Auckland, New Zealand, captures the paradox of the 'liveable' city: for many people living there, it is not. Three years earlier, Auckland launched its first metropolitan strategic spatial plan and announced the goal of becoming the world's most liveable city, building on global rankings that awarded the third place to the city in 2012 (Mercer, 2012). However, the rapid growth of a house price bubble and protracted political disputes over rapid transit investment undermined this goal (McArthur, 2017), which the city abandoned in 2016. Why does liveability discourse persist in urban policy when, in practice, it is so difficult to achieve? Close observation of liveability discourse 'in action' while conducting doctoral research in Auckland between 2013-2016 prompted this line of inquiry.

Liveability discourse has shown extraordinary longevity within urban policy and research. The term is ubiquitous and taken-for-granted within urban strategies and policy documents (Clarke and Cheshire 2018) and has spread beyond local and national policies to feature in guidance from international organisations including UN-Habitat, the OECD, and the World Bank (OECD 2014, UN-Habitat 2008, 2016, World Bank 1996). Following the 2018 release of the Economist Intelligence Unit's annual rankings, widespread media coverage reflected their ongoing importance to city branding and perceptions of success. Movements in the rankings were publicly debated in Singapore (Varma 2018), India (Khajuria 2018, Nair 2018), Australia (Waterford 2018), South Africa (Chiwanza 2018) and the United States (Im 2018). Manchester's rise within the rankings - despite a $40 \%$ increase in homeless population the previous year (Williams 2018) - was promoted by the mayor of Greater Manchester mayor's, claiming that 'Manchester has been names as the UK's best city to live in, according to the renowned EIU Global Liveability Index. Great news - shows the world what we all knew’ (@MayorofGM 2018).

Urban discourses are continually evolving and have a central role in shaping policy and decision-making. Scott's (1998) 'Seeing like a State' showed how discourses and their 
implied categorisation allow a government to make sense of the world they govern, often adopting reductionist perspectives that select which aspects of the world can be altered and controlled. On the one hand, discourses are invaluable to communicate logic and narrative required to enable transformation in cities. On the other hand, discourses tend to privilege a simplistic notion of what a city is - or should be - despite its empirical complexity (Amin 2013, Simone and Pieterse 2018). Urban discourses can also obfuscate reality through the use of language and implicit assumptions, suppressing 'critical questions' (Marcuse 2015).

Liveability has characteristics of a buzzword, carrying strong performative power as it means different things to different actors and evades conflicting views (Vincent 2014). However, buzzwords tend to be short-lived. The longevity of liveability discourse warrants further examination of what this discourse entails and its rhetorical power, to explain how it has maintained its prominence. In what follows, the recent development of liveability discourse is surveyed to understand its global reach, followed by discourse analysis to unpack how it frames urban problems, selects and sorts phenomena, and builds a causal narrative for change. The final section explores how a focus on livelihoods - rather than livability - can reinvigorate policy debates and choices towards more just outcomes, and what role critical urban scholarship can play in this shift of perspective.

\section{Current imaginaries of the Liveable City}

Since its emergence in Dutch spatial planning in the 1950s (Kaal 2011), liveability has travelled widely across geographical contexts and remains prominent amongst planners and politicians. McCann $(2007,2013)$ showed how liveability discourse fused neatly with entrepreneurialism and city-regionalism in the United States. This narrative linked liveability, economic development and international competitiveness, seemingly congruent with the creative class theory. This fusion narrowed the definition of liveability, concealing distributional issues, and faced strong resistance at the neighbourhood level. Despite the failure to deliver on liveability goals in this context, the discourse travelled further to Canada (Holden and Scerri 2013), Australia and New Zealand (Wetzstein 2013), Singapore (Teo 2014), the Gulf region (Ewers 2017) and China (Fu and Zhang 2017). Indices popularised the 'liveable city' as a goal for policymakers seeking to develop globally competitive and attractive cities (Holden and Scerri 2013). 
Figure 1 illustrates the growth in liveability's popularity in the news media ${ }^{1}$. There is growth in Oceania, Asia, and Africa and Europe since the mid-2000s, showing the most recent upsurge in the discourse's popularity. This paper focuses on the mobilisation and influence of the discourse across this period, building on the work of Ley (1990) and McCann (2007).

[Insert Figure 1 here]

The continued spread of liveability discourse, despite three decades of academic critique and prominent policy failures, raises questions for debate: how has the discourse maintained its power, and what results from this form of rhetoric and knowledge production? Alongside the discourse itself, ideas and concepts travel through international policy networks and knowledge flows (Legrand 2016), so the intersection between discourse and knowledge production is taken as the point of departure in this inquiry. This approach illustrates the relationships between discourse and expert knowledge production and the dynamic processes of constructing and negotiating policy frames. These relationships, as we shall explore, are not unidirectional, as liveability discourses are themselves shaped by the market for urban expertise and demand for specific knowledge from policymakers. May (2017, p.6) warns of 'narrowly based futures and ideas of expertise' that undermine aims for democratic and inclusive urban development, calling for such imaginaries to be 'consigned to the bonfire of the vanities'. We consider whether liveability should be consigned to such a bonfire. If so, understanding how it builds discursive power can reveal opportunities to develop tactical counter-discourses (Schafran 2014) that reconnect policy narratives to urban livelihoods and the everyday experience of the city.

Over the past decade, adoption of liveability in urban discourse is most prominent in Australasia, Asia, and international development organisations. Definitions of liveability vary widely at different scales of governance. National policies are influenced by the imperative for cities attain the status of a 'global city', which looks to strategic competitors to define what a city requires to gain a comparative advantage, often including international airports, high-amenity urban environments, and rapid transit systems (Baker and Ruming 2015).

\footnotetext{
${ }^{1}$ Search terms included: (urban OR city OR cities) AND (livable OR liveable OR livability OR liveability), excluding duplicates (Source: nexis.com)
} 
Strategic plans define liveability according to broad outcomes: quality of life, people-centred urban design, environmental sustainability and attractiveness to investors. Table 1 provides examples of the conceptualisations of urban liveability promoted by a selection of cities and international organisations, showing how liveability is a familiar descriptor alongside other concepts related to wellbeing, culture, and sustainability. Similar usage of the term across diverse geographical settings shows how it has become embedded in urban discourse at the global scale. These examples also illustrate how liveability is framed as a singular concept, and there is limited qualification of how it might be different for different population groups within a city. The cities are selected to reflect regions where liveability discourse is prominent in urban policy and media. International organisations' adoption of liveability discourse is significant as they provide global thought-leadership for policymakers and also legitimate specific concepts for urban policy (Theodore \& Peck 2011). These examples of liveability discourse are used within the discourse analysis in Section 3.

[Insert Table 1 here]

\section{Deconstructing liveability discourse: rhetorical work and policy framing}

To understand how liveability operates as a discourse, and the types of action spurred, this paper examines the rhetorical work (Rein and Schön 2012) done, and resulting policy frames (Schön 1983) generated. Liveability discourse is deconstructed to show how it mobilises ideas and language to define particular frames for urban policy intervention. This paper focuses on the rhetorical work and framing effects of urban liveability across the past decade, seeking to build on the conclusions of McCann (2007) to explain the specific discursive power and persistence of liveability discourse.

Rhetorical work refers to the use of 'urban liveability' as a linguistic apparatus to define the frame for city's problems and objectives, and in turn, the scope for potential interventions (Jensen and Richardson 2005). Policy frames create 'both a model of the world, and a model for subsequent action' (van Hulst and Yanow 2016, p.98), cited in (Metzger and Wiberg 2017). Frames define the context for interventions, highlight processes and phenomena, and justify potential actions and the roles that different actors have to play. Discursive frames shape the demand for, and production of, policy-relevant knowledge through what is revealed and concealed. For policymakers, liveability discourse creates a demand for expert 
knowledge, to measure the various tangible and intangible characteristics that qualify whether a city is 'liveable'. Liveability discourse and the knowledge that supports it presents a distinct and partial model of the world, which spurs specific forms of action (or inaction) by the state.

How do specific frames assert their dominance in policy discourses, and permeate the city through actual interventions? Callon et al. (2002, p.199) show the dynamics and temporality of the process that underpins the qualification of 'things'. The quality of a product - in this case, a city - is 'obtained at the end of a process of qualification, and all qualification aims to establish a constellation of characteristics, stabilised at least for a while, which is attached to the product and transform it temporarily.' In the following analysis, annual liveability rankings demonstrate the temporary stabilisation of a city's qualities, as they bring into focus specific characteristics of cities and their amenities, making them coherent with broader narratives and potential objects of policy interventions. This process is dynamic, since liveability is negotiated and re-articulated from year to year. Indices impose performative power by asserting a fixed, but temporary, definition of liveability to different cities (Callon, 2010) and by ranking them.

A dynamic concept of framing is essential to unpack these processes and reveal the power dynamics of knowledge production. These dynamics are central to understand why and how particular definitions of liveability have dominated policy discourses and resulting interventions. On the one hand, framing has to be recognised as a political process, since the assumed 'model of the world' and of 'model for action' is shaped by power and conflicts (Richardson and Jensen, 2003). Given the multiple interpretations of liveability reflected in Table 1, this approach is attuned to the disparate and tenuous - yet enduring - nature of liveability discourses. On the other hand, understanding how specific frames impose discursive power to shape a city, we must consider the tactics and tools used by different actors involved in the process of framing. In what follows, the 'work of framing' of liveability discourses is critically evaluated, focusing on three ways in which framing progressively works towards the translation of ideas into policy interventions: sense-making; selection, sorting and categorisation of phenomena; and storytelling (van Hulst and Yanow 2016).

\subsection{Sense-making}

Liveability discourse has a sense-making role, by 'intersubjectively construct the meanings of the policy-relevant situations' amongst policymakers and stakeholders (van Hulst and Yanow 
Several international organisations also adopted liveability discourse. For UN-Habitat and the World Bank, the concept related to each organisation's developmental focus: actions were identified in terms of poverty eradication, basic service provision, equal rights, health and access to finance. For the OECD, liveability discourse followed a similar narrative to nation states, focusing on the quality of infrastructure and green spaces to support economic prosperity and attract mobile capital, workers and visitors.

The meanings constructed by city governments prioritise aspirational objectives that resonate with a range of actors, but do not acknowledge that these outcomes are often in tension with each other. Vienna's plan asserted that 'the quality that renders Vienna so attractive is to be experienced by all - old and young, long-time residents and newcomers as well as visitors' (City of Vienna 2014, p.13), without acknowledging that these groups may value urban qualities in different ways. As a frame for action, liveability does not acknowledge social and 
economic disparities in cities, and how these can be catered for through planning, service provision, and governance (Lloyd 2016). In addition, the positioning of liveability within urban planning and policy discourse carried an implicit assumption that liveability can be governed, or indeed delivered, through planning processes or public service provision. The scope and agency of local governments to deliver liveability can be limited by national policies in areas such as economic policy and income redistribution, housing, national security strategies and migration policies (Clark and Moonen 2017).

The apparent weakness of liveability as a discursive tool to making sense of human needs, is perhaps the same characteristic that enabled liveability discourse to permeate policy debates and influence, in various ways, urban policy for half a century. As with the 'smart' or 'sustainable city' (Rydin, 2012), the vague terms act to coalesce the interests of various types of actors (Hatuka et al., 2018). The recent iterations of liveability discourse outlined in Section 3 maintain the vague conceptualisation, providing claims that are not objectionable to any specific party. Since it is not clear what the implications are for planning, service provision and investment, the discourse has limited rhetorical power to compel action. Through knowledge production and the work of experts, however, a very vague term can be given 'policy substance'. Indeed, liveability's lack of specificity left the discourse vulnerable to appropriation, in the manner of the 'policy primeval soup' (Kingdon 1984). In what follows, we explore how the selective process of naming and categorising operated by a sample of urban liveability indexes contributed to qualify and reify specific characteristics of the liveable city.

\subsection{Selecting, naming and categorising}

Liveability's discursive power can be understood in conjunction with expert knowledge production. Specifically, the way that frames and accompanying urban 'expertise' select and order specific concepts and phenomena. Since the term 'liveability' does not have a specific, agreed-upon meaning, knowledge producers that actively 'fill in' this concept do actively select and categorise phenomena. Indices and rankings have gained policy traction in recent years (Kitchin et al. 2015, Robin et al. 2017, Robin and Acuto, 2018). The popularity and widespread dissemination of composite liveability indexes, notably those promoted by the Economist Intelligence Unit, $\mathrm{PwC}$, Mercer and Monocle, have provided quantifiable and comparable measures of urban liveability. As these metrics aggregate information to form 
composite or average measures, they order the importance of different phenomena that they deem important for liveability. Aggregation of metrics subsequently conceals this and the complexity of a 'people-centred' approach articulated in liveability discourses is homogenised to a single, city level metric. These rankings emphasise and make visible, through quantification, the preferences and preoccupations of a relatively privileged class of urban dwellers (McCann, 2007), masking inner-city disparities by aggregating information at the city level.

Table 2 illustrates the indicator categories included across different sources of liveability indices. The table shows significant variation across indices, regarding the number of metrics, and sectors covered. The EIU Global Liveability Ranking and Global Liveable Cities Index both focus heavily on the political environment, consumer goods and public services, while the PwC Cities of Opportunity index measures a much broader range of factors across the economic and financial conditions, as well as the built and natural environments. ISO 37120 , produced by the International Standards Organisation, provides a broad survey of measures across different sectors and is the only index that includes income inequality. However, this index is not prominent in international media and does not generate annual rankings.

\section{[Insert Table 2 here]}

The metrics summarised in Table 2 reflect the preferences of a specific class: well-educated, internationally-mobile individuals and families who placed a high priority on the quality of architecture and urban design, restaurants and entertainment, public safety, schools, and access to airports for international travel. Inequality or deprivation is not directly measured, and the use of average values overlooks the experiences of low-income or disadvantaged groups. This show how liveability gives legitimacy to the consumption preferences of a particular class (Ley 1990), translating it into policy goals. The notion that liveability can be meaningfully reflected through a global ranking implicitly assumes that the reader is globally mobile. If not, it is of little utility or even reassurance that a city is more 'liveable' than another.

The production of rankings by private sector consultancies and lifestyle media headquartered in North America and Europe may explain the bias toward an audience of internationallymobile consumers, with similar consumption preferences. As a result, the transformation of 
liveability aspirations into rankings or indices, as ways of knowing and quantification, gave a limited representation of a complex and variable subject. Liveability is a polyvocal concept, which, as previously highlighted, has supported its popularity but also made it 'up for grabs'. The informative ability of liveability indices is limited (Miller 2001): the aggregation of the different dimensions of liveability conceals the diversity of cities and individual preferences that are central to determine the quality of life in different climates, and different stages of life. It does, however, provide the precise form of expert knowledge needed to embed liveability within the competitive cities paradigm, by reducing liveability strategies to narrow interventions that can easily be tracked and measured, or by providing proof of success (without linking this success to particular interventions) shall a city move up the liveability ladder.

\subsection{Building common narratives}

The narrative power of liveability discourse lies in the way it connects phenomena and processes to communicate 'what needs to be done - past, present, and future - corresponding to the plot line of a policy story' (van Hulst and Yanow 2016). Through quantification and categorisation, different issues that make up for - or hinder the realisation of - the Liveable City are made visible. As a result, those can be framed as legitimate policy interventions and can be integrated into broader story-telling to justify the implementation of particular policies.

The influence of liveability on the framing and boundary-setting of policy interventions has taken two forms. Firstly, the discourse combined with New Public Management approaches to governance, necessitating specific metrics, supporting the rise of global liveability indexes. These indices aligned neatly with competitiveness discourses: Bristow (2005) outlines how the pre-eminent conception of regional competitiveness equates to 'attractiveness', or the capacity of the region to compete with other places for mobile capital. Liveability is couched within these conceptions, as far as it creates amenities to attract high-skilled workers to improve local economic competitiveness. This approach places strategic emphasis on the ability of a region to attract and retain innovative firms, skilled labour, mobile investment and central and supranational government subsidies and funds, and an overriding focus on the pursuit and measurement of their success in doing so relative to other places. Secondly, the uptake of liveability in urban discourse shows that it was treated a 'matter of fact', instead of 
a 'matter of concern', with limited critique on the underlying purpose and politics (Latour 2004). Treating liveability as a matter of fact, without questioning the implicit assumptions and value judgements, meant that important questions were not confronted by local officials. Liveability, as a vague concept legitimised by global rankings, concealed issues around equity and urban planning by displacing local knowledge and therefore eliminating possibilities for public deliberation on appropriate and desirable goals for cities. Indeed, the mobilisation of liveability discourse reflects the 'performances' of buzzwords highlighted by Vincent (2014): generating matters of concern (rather than matters of fact), setting attractive goals, and forming unstable collectives. Buzzwords have no consistent meaning, but strong resonance and positive connotations with an audience. However, this power also explains why buzzwords become problematic. Liveability's resonance influenced discourse with such ease that it was not received critically enough at the outset, and throughout the processes of sense-making and selecting examined in the previous sections.

Liveability performed adeptly as a buzzword in urban discourse, but unfortunately, the intended goals of framing knowledge production and action to improve individual lives did not materialise. Indeed, in light of its poorly-defined goals, liveability was reduced to a generalised policy prescription to improve walkability, public space upgrades, cycle lanes, rapid transit, environmental remediation - fostered by global rankings and expert consultants that assert inter-city competition at the centre of their practice. These interventions are often beneficial, however, within a land-use and housing system that is inequitable, they had restricted potential to improve liveability in an inclusive and meaningful way, for all people. For example, in the context of speculative property markets with insufficient provision for affordable housing, investments to improve rapid transit services and public spaces fuelled gentrification and excessive inflation in property values in Vancouver (Jones and Ley 2016), Atlanta (Immergluck and Balan 2017) and Austin (Dooling 2017). Liveability narratives are often treated as little more than an 'urban development script' to support place branding and foster development, as found in Ontario, Canada (Cleave et al. 2017). Equally, the narration of liveability around Singapore's national economic strategies over individual needs negated the legitimacy of individuals and communities and implied a pre-determined set of policy interventions (Teo 2014). 


\subsection{Dynamics of framing}

Evaluation of the influence of urban liveability discourse(s) allows us to question its value at a time when governance actors at all scales face important challenges to ensure that urban areas meet the needs of current and future generations sustainably and inclusively (UN Habitat 2016). Elaborating these three dimensions of discursive framing suggests that liveability has had more influence because of the 'fuzzy' conceptualisation, giving legitimacy to other agendas, than direct interventions to improve quality of life for everyone living in the city. The dynamics of discursive framing show that liveability discourses evade the trade-offs and potential conflicts across populations that hold diverse preferences and needs, by eluding concrete definition and subtly concealing the trade-offs that must be negotiated as cities develop and change. Like other buzzwords such as resilience, sustainability and smart-ness, this conceptual 'fuzziness' allowed the liveability discourse to be taken up by a wide range of actors. Indeed, definitions and mobilisations of the term vary widely between urban planning professionals, local politicians, community actors, academics, research funding agencies, global actors and media sources. The widespread adoption of the 'fuzzy' concept enables an illusory consensus to form, which is politically useful as it avoids direct confrontations with voters or interest groups. Liveability discourse also allays possible tensions between the needs of current and future residents: existing residents are assured that quality of life is prioritised, while liveability also operates as a way of appealing to future residents, to attract a talented, high-skilled workforce. For example, the Auckland Plan contends that liveability 'expresses our shared desire to create a city where all people can enjoy a high quality of life... which is attractive to mobile people, firms, and investors' (Auckland Council 2013). In this way, liveability temporarily avoids the politics of urban development but does not confront ongoing conflicts and trade-offs.

The politics of expertise and power negotiations between different professions are revealed in the way the discourse favours modes of quantification. Promotion of liveability rankings and indices developed by global media and consultancies placed these knowledge producers at the centre, reducing the relative influence of architects, planners, urban designers, engineers, psychologists and sociologists to speak authoritatively on cities. The work of urban designer and architect, Jan Gehl, was commissioned for the liveability agenda in Sydney and Melbourne (McNeill 2011), however, the potential for this expertise on urban environmental quality to address wider equity issues across the city was limited by local officials' framing, 
which negated the diversity of embodied urban experiences. While technical professions such as engineering and planning readily adopted liveability discourses to build value into their practice, the vague definitions proposed by liveability discourses limited its ability to influence technical design or planning practices. Liveability formed power at the juncture of discourse and expertise, reducing the legitimacy of other forms of knowledge. Liveability enabled a 'culture of expertise to emerge that is at odds with democracy through a separation of the forms of justification it deploys and the context of its application' (May 2017). Production of powerful forms of expertise through liveability rankings disconnected knowledge production practices from the local context, thereby limiting opportunities for democratic input. What claims to be a people-centred approach to cities has privileged the preferences of a specific class of urban citizens - or rather, urban consumers. This paper, therefore, challenges the implicit assumptions of the urban liveability discourse and its underlying knowledge base. Liveability discourse and its expert knowledge are deficient in catering for the diverse needs of urban populations and in acknowledging the value of universal access to social goods such as housing, transport, energy, water and sanitation.

\section{From urban liveability to urban livelihoods: reconnecting policy to everyday life in the city}

Reviewing the framing effects of liveability discourse, its rhetoric and performative work, shows how discourse is vulnerable to appropriation by other, often agendas, even those that are contradictory. From the outset, liveability had the potential to frame urban policy problems in a way that dramatically improved quality of life and prioritised living standards within policy and planning. The term isn't inherently problematic, but the way it has been mobilised is where our primary critique is targeted. This review showed that the discourse followed a different trajectory, and the juncture between discursive framing and specific forms expert knowledge production was used tactically to appropriate liveability toward exclusionary agendas. Liveability thus became a form of powerful knowledge (Brenner and Schmid 2014; Kirby 2013): accepted wisdom on what cities should prioritise in policy and public investment. While improving quality of life for a city's residents is difficult to contest, the adopted definitions of liveability catered to wealthy, educated, cultural elites. Discourse framed urban liveability as a uniform, city-wide outcome, rather than reflecting the actual plural nature of individual experiences. Complementary to this, production of rankings and indicators aggregated data to the city level, eliminating opportunities to recognise difference 
or inequality. The disconnect between liveability discourse, rankings, and the realities of individual experience drew critique and cynicism toward rankings and the value of liveability strategies (Jacobs 2015). Considering counterfactuals to urban liveability also reveals the limitations of this discourse. Urban discourse in regions in the Global South - albeit under the 'widespread overlay of international aspirations to global competitiveness' (Parnell and Robinson 2006) - has framed cities according to international development agendas: focused on basic needs for housing, sanitation and public service provision (van Lindert 2016).

Dominant urban discourse in the Global North is comparatively deficient in attending to the needs of the urban poor. The overall wealth and living standards in cities in the Global North are higher, but wealthier cities within this group have higher rates of urban poverty, inequalities and socio-economic deprivation. This issue echoes a similar critique of claims to urban success, as contended by Massey (2005, p. p.157): 'the fact that London's 'success' is one of the dynamics producing poverty and exclusion implied at least a query as to the meaning of this word 'successful'. We contend that such cities are not victims of their own success, but victims of their own definition of success. Drawing from the suggestion of May (2017) to 'give up prerogatives constituted in narrowly based futures and ideas of expertise... to consign these ways to the bonfire of the vanities', should liveability and associated expert knowledge, in their current forms, be dispensed with? The reduction of liveability to a singular characteristic within expert knowledge has discursively cast aside the diversity of human needs present in cities, amounting to yet another form of 'telescopic urbanism' (Amin 2013). Telescopic urbanism obscures the ability to identify where low-income or disadvantaged populations cannot meet their basic needs. Indices and rankings may have a place within global urban knowledge systems, but their effect in glossing over urban inequalities, even in relatively prosperous cities, warrants reconsideration of the underlying expertise (Robin and Acuto, 2018).

\section{Engaging with the knowledge politics of urban liveability}

Creating high quality, safe and sustainable urban environments for urban dwellers remains a laudable objective at a time where the majority of the world population - and increasingly so 
- is living in cities. So how can critical urban knowledge be leveraged to refocus this agenda towards people and their livelihoods?

Re-appropriation of liveability discourse could bridge urban thinking across the Global North-South divide by interrogating the modes of production of urban knowledge. Within academic debates on decolonising urban theory, there is a critique of the production and mobilisation of knowledge: encompassing scientific evidence, historical and technical knowledges that are used to construct expertise on urban policy and planning. Comparison across the Global North-South shows that urban policymaking planning in the Global South tends to take a more developmental approach, explicitly acknowledging the imperative to meet basic needs and improve living standards (Barnett \& Parnell 2017; Robinson 2005). While living standards are significantly higher in wealthier countries in the Global North, urban practice is often deficient in addressing inequality and frequently overlooks the needs of low-income or disadvantaged populations (Parnell and Robinson 2006). Breaking down the Global North-South divide in urban thinking can bring this issue to the fore: accompanied by the Sustainable Development Goals, it may bring cities in the Global North to account for the paucity of urban planning for the poor.

Urban scholars have a role to play in that endeavour. Urban knowledge within and outside academia does not have the coherence of agreed methods and standards that characterise a disciplinary paradigm in the natural sciences (Neuman and Hull 2009) - rather it is shaped by the 'weak disciplinisation' of hybrid research fields and practitioner knowledge (Van Damme 2005). The knowledges mobilised to make sense of urban phenomenon do not comprise a unified theory or framework for understanding cities, but rather a patchwork of partial theories, empirical evidence, and normative paradigms across epistemologically fragmented disciplines, namely planning, economics, political economy, environmental science, engineering and public policy (Acuto et al., 2018). Acknowledging the in-built differentiated nature of urban knowledge highlights the need to deliberate with communities affected by urban development may have steered liveability discourse to a more beneficial set of outcomes. For example, choosing to interpret urban liveability as a design principle can shape urban planning and policy in a way that retained the flexibility to local needs and attention to the human dimension of urban success. In this way, success could be defined through coproduction, as local actors explore what liveability means to them, how it could be enhanced and monitored (not necessarily through quantitative assessments). 
As argued elsewhere: 'Especially in urban environments, every good idea can be co-opted by power, and the question we must begin asking is how we can become powerful enough to ourselves co-opt whatever concept can help - including creativity, entrepreneurialism, sustainability, resilience or freedom, all of which as ideas and aspirations could be quite useful' (Schafran 2014). Liveability raises the same question. Its malleable nature also opens it up to broader discussions and new lines of thinking emanating from the lived experience and livelihoods of urban dwellers globally. In light of the debates reviewed in this paper, engaged academics can learn from the powerful combination of discourse and expert knowledge. The powerful performative qualities of this combination show that academics seeking to counter the hegemonic power of discourses such as liveability can build power through alternative forms of knowledge, and ways of knowing, that are compelling to urban practitioners, politicians and the public. 


\section{References}

Abu Dhabi Urban Planning Council (2017) Plan Abu Dhabi 2030. Technical report, United Arab Emirates Government. Accessed 12 October 2017, https://www.ecouncil.ae/PublicationsEn/plan-abu-dhabi-full-version-EN.pdf.

Amin A (2013) Telescopic urbanism and the poor. City 17(4): 476-492.

Auckland Council (2013) Auckland Plan. Statutory plan, Auckland Council. Accessed 5 July 2017, http://theplan.theaucklandplan.govt.nz/.

Baker T and Ruming K (2015) Making 'Global Sydney': Spatial imaginaries, worlding and strategic plans. International Journal of Urban and Regional Research 39(1): 62-78.

Barnett C and Parnell S (2017) Spatial rationalities and the possibilities for planning in the New Urban Agenda for Sustainable Development. In: Bhan G, Srinivas S, Watson V (eds.) The Routledge Companion to Planning in the Global South, chapter 1. London: Routledge, pp. 25.

Brenner N and Schmid C (2014) The 'urban age' in question. International Journal of Urban and Regional Research 38(3), 731-755.

Bristow G (2005) The limits to competitiveness. In: Critical Reflections on Regional Competitiveness: Theory, Policy, Practice, chapter 6. New York, NY: Routledge, pp.121138.

MayorofGM (2018, August 14). "Not only have we shot up the ranks faster than any other European city - but \#Manchester has been named as the UK's best city to live in, according to the renowned@TheEIU Global Liveability Index. Great news - shows the world what we all knew". 14 August 2018, 1.28am. [Tweet]. Retrieved from https://twitter.com/MayorofGM/status/1029283677233131525.

Callon M, Meadel C and Rabeharisoa V (2002) The economy of qualities. Economy and Society 31(2), 194-217.

Callon M (2010) Performativity, misfires and politics. Journal of Cultural Economy 3(2), 163-169.

Centre for Liveable Cities (2014) Liveable \& sustainable cities: a framework. Singapore: Civil Service College.

Chiwanza, T.H. (2018, August 14) The ten least livable cities in the world - African cities dominate the list. The African Exponent. Retrieved from https://www.africanexponent.com/post/9071-africa-cities-dominate-the-list-for-the-tenleast-liveable-cities-in-the-world. 
City of Vienna (2014) Step 2025: Urban Development Plan Vienna. City of Vienna.

Accessed 2 October 2017,

https://www.wien.gv.at/stadtentwicklung/studien/pdf/b008379b.pdf.

Clark G and Moonen T (2017) World Cities and Nation States. Oxford: Wiley Blackwell.

Clarke A and Cheshire L (2018) The post-political state? The role of administrative reform in managing tensions between urban growth and liveability in Brisbane, Australia. Urban Studies DOI: 10.1177/0042098017753096.

Cleave E, Arku G, Sadler R and Gilliland J (2017) Is it sound policy or fast policy?

Practitioners' perspectives on the role of place branding in local economic development. Urban Geography 38(8), 1133-1157.

Conger B (2015) On livability, liveability and the limited utility of quality-of-life rankings. SPP Communique, University of Calgary 7(4), 1-8.

Development Bureau and Planning Department (2007) Hong Kong 2030 Planning Vision and Strategy. Hong Kong Special Administrative Region Government. Accessed 4 June 2017, http://www.pland.gov.hk/pland_en/p_study/comp_s/hk2030/eng/finalreport/.

Dooling S (2017) Ecological gentrification: The dynamics of poverty and wealth that that undermine climate change goals in Austin, TX. In: American Association of Geographers Annual Meeting, Contradictions of the Climate Friendly City 1. Boston, MA.

EIU (2015) Global Liveability Ranking 2015. Economist Intelligence Unit. Retrieved from: www.eiu.com/liveability2015.

Giap, K and Kaur, S (2016) Measuring Abu Dhabi’s liveability using the global liveable city index (GLCI). World Journal of Science, Technology and Sustainable Development 13(3):205-223.

Hall P (2002) Cities of Tomorrow: an Intellectual History of Urban Planning and Design in the Twentieth Century. 3rd edition. Oxford University Press.

Hatuka T, Rosen-Zvi I, Birnhack M, Toch E and Zur H (2018) The Political Premises of Contemporary Urban Concepts: The Global City, the Sustainable City, the Resilient City, the Creative City, and the Smart City, Planning Theory \& Practice, 19(2), 160-179.

Hebbert M (2003) New Urbanism - The movement in context. Built Environment 29(3), 193209.

Holden M and Scerri A (2013) More than this: Liveable Melbourne meets liveable Vancouver. Cities 31, 444-453. 
Im J (2018, August 14) This is the most liveable city in the world. CNBC. Retrieved from https://www.cnbc.com/2018/08/14/global-liveability-index-2018-vienna-most-liveablecity-in-the-world.html.

Immergluck D and Balan T (2017) Sustainable for whom? Green urban development, environmental gentrification, and the Atlanta Beltline, Urban Geography, 39(4), 546-562.

International Organisation for Standardization (2014) Sustainable development of communities -- Indicators for city services and quality of life (ISO/DIS Standard No. 37120). Accessed May 9, 2018, https://www.iso.org/standard/62436.html.

Jacobs, K.A. (2015). Australian Unintended Cities. Geographical Research 5(3), 333-335. Jensen, O.B. and Richardson, T. (2005) Branding the contemporary city - urban branding as a regional growth agenda? Plenary paper for Regional Studies Association Conference 'Regional Growth Agendas', Aalborg, Denmark, May 2005.

JLL and The Business of Cities (2017) Decoding City Performance: The Universe of City Indices 2017. http://www.jll.com/cities-research/Documents/benchmarking-futureworldof-cities/JLL-Decoding-City-Performance-2017.pdf. Accessed 20 October, 2017. Jones C and Ley D (2016) Transit-oriented development and gentrification along Metro Vancouver's low-income SkyTrain corridor. Canadian Geographer 60(1), 9-22.

Kaal H (2011) A conceptual history of livability. City 15(5), 532-547.

Khajuria A (2018, August 23) Politicians blamed for city's poor show on liveability index. The Tribune. Retrieved from https://www.tribuneindia.com/news/jammukashmir/politicians-blamed-for-city-s-poor-show-on-liveability-index/641679.html. Kingdon J (1984) Agendas, Alternatives and Public Policies. New York, NY: Harper Collins. Kirby A (2013) Cities and powerful knowledge: An editorial essay on accepted wisdom and global urban theory [Part I]. Cities 32(1), S3-S9.

Kitchin R, Lauriault T and McArdle G (2015) Knowing and governing cities through urban indicators, city benchmarking and real-time dashboards. Regional Studies, Regional Science 2(1), 6-28.

Latour B (2004) Why has critique run out of steam? From matters of fact to matters of concern. Critical Inquiry 30, 225-248.

Lees L and Demeritt D (1998) Envisioning the livable city: The interplay of "Sin City" and “Sim City" in Vancouver's planning discourse. Urban Geography 19(4), 332-359.

Legrand T (2016) Elite, exclusive and elusive: transgovernmental policy networks and iterative policy transfer in the Anglosphere. Policy Studies 37(5), 440-455.

Ley D (1990) Urban liveability in context. Urban Geography 11(1), 31-35. 
Lloyd K (2016) Where is the 'social' in constructions of 'liveability'? Exploring community, social Interaction and social cohesion in changing urban environments. Urban Policy and Research 34(4), 343-355.

Marcuse P (2015) Depoliticizing urban discourse. Cities 44, 152-156.

Massey D (2005) For Space. London, United Kingdom: Sage.

May T (2017) Urban crisis: Bonfire of vanities to find opportunities in the ashes. Urban Studies 54(9), 2189-2198.

McArthur J (2017) Auckland: Rescaling governance and post-suburban politics. Cities 64, 79-87.

McCann E (2007) Inequality and politics in the creative city-region: questions of livability and state strategy. International Journal of Urban and Regional Research 31(1), 188-196.

McCann E (2010) Urban Policy Mobilities and Global Circuits of Knowledge: Toward a Research Agenda. Annals of the Association of American Geographers 101(1), 107-130.

McCann E (2013) Policy boosterism, policy mobilities, and the extrospective city. Urban Geography 34(1), 5-29.

McNeill D (2011) Fine grain, global city: Jan Gehl, public space and commercial culture in central Sydney. Journal of Urban Design 16(2), 161-178.

Mercer (2012) Quality of Living Rankings. Mercer Intelligence. Retrieved from https://www.imercer.com/content/mobility/quality-of-living-city-rankings.html.

Metzger J and Wiberg S (2017) Contested framings of urban qualities: Dis/qualifications of value in urban development controversies. Urban Studies

DOI:10.1177/0042098017712831.

Miller, P. (2001). Governing by numbers: Why calculative practices matter. Social Research 68(2), 379-396.

Nair, S. (2018, August 16) Economist Intelligence Unit survey: Delhi ranks 112 on Global Liveability Index, Mumbai 117. Indian Express. Retrieved from https://indianexpress.com/article/india/economist-intelligence-unit-survey-delhi-ranks112-on-global-liveability-index-mumbai-117/.

Neuman, M. and Hull, A. (2009). The futures of the city region. Regional Studies 43(6):777787.

New Zealand Herald (2016) Phil Goff keen to drop ex-mayor's slogan in favour of a brandnew vision for Auckland. 29 October 2016, http://www.nzherald.co.nz/nz/news/article.cfm?c_id=1\&objectid=11728451, Accessed 15 October 2017. 
OECD (2014) How's life in your region? Accessed 12 July 2017, http://www.oecd.org/regional/how-is-life-in-your-region.htm.

Parnell S and Robinson J (2006) Development and Urban Policy: Johannesburg's City Development Strategy. Urban Studies 43(2), 337-355.

Parnell S and Robinson J (2012) (Re)theorizing cities from the Global South: Looking beyond neoliberalism. Urban Geography 33(4), 593-617.

Rein M and Schön D (2012) Frame-reflective policy discourse. In: Wagner P, Weiss C, Wittrock B and Wollman H (eds.) Social Sciences and Modern States: National Experiences and Theoretical Crossroads, chapter 12. Cambridge University Press, pp. 262-289.

Richardson, T., \& Jensen, O. B. (2003). Linking discourse and space: Towards a cultural sociology of space in analysing spatial policy discourses. Urban Studies, 40(1):7-22

Robin E, Brill F (2018). The global politics of an urban age: creating 'cities for all' in the age of financialisation. Palgrave Communications 4(1), p.3

Robin E, Steenmans K and Acuto, M (2017). Harnessing inclusive urban knowledge for the implementation of the New Urban Agenda. Urban Research \& Practice, 1-19.

Robinson J (2005) Ordinary Cities: Between Modernity and Development. London: Taylor \& Francis.

Rydin, Y., 2012. Policy networks, local discourses and the implementation of sustainable development. In: Baker S (ed.) Politics of Sustainable Development, pp. 161-182. London: Routledge.

Schafran A (2014) Debating urban studies in 23 steps. City 18(3), 321-330.

Schön D (1983) The Reflective Practitioner. London, United Kingdom: Ashgate.

Scott J (1998) Seeing like a State: How Certain Schemes to Improve the Human Condition Have Failed. New Haven, CT: Yale University Press.

Simone A and Pieterse E (2017) New Urban Worlds: Inhabiting Dissonant Times. Cambridge, UK: Polity Press.

Singapore Government (2014) The Planning Act: Master Plan Written Statement. 29 October 2016, https://www.ura.gov.sg/-/media/User\%20Defined/URA\%20Online/masterplan/master-plan-2014/Written\%20Statement\%202014_uptd18jan16.pdf?la=en, Accessed 15 October 2017.

Teo S (2014) Political tool or quality experience? Urban livability and the Singaporean states global city aspirations. Urban Geography 35(6), 916-937. 
Theodore N and Peck J (2011) Framing neoliberal urbanism: Translating 'commonsense' urban policy across the OECD zone. European Urban and Regional Studies 19(1), 20-41.

UN-Habitat (2008) Broad-Based Partnerships as a Strategy for Urban Livability: An Evaluation of Best Practices. Technical report, United Nations, New York.

UN-Habitat (2016) New Urban Agenda. Technical report, United Nations, New York. Van Damme S (2005) Les sciences humaines 'a l'epreuve de la ville: les enjeux d'une archeologie des savoirs urbains (XVIIe-XXe siecles). Revue d'histoire des sciences humaines 12: 3-17.

van Hulst M and Yanow D (2016) From policy 'frames' to 'framing': Theorizing a more dynamic, political approach. American Review of Public Administration 46(1), 92-112.

van Lindert P (2016) Rethinking urban development in Latin America: A review of changing paradigms and policies. Habitat International 54(2), 253-264.

Varma A (2018, August 24) Singapore continues to rank highly in liveability polls. Straights Times. Retrieved from https://www.straitstimes.com/singapore/singapore-continues-torank-highly-in-liveability-polls.

Vincent B (2014) The politics of buzzwords at the interface of technoscience, market and society: the case of public engagement in science. Public Understanding 23(3), 238-253.

Walmsley D (1988) Urban Living: The Individual in the City. Harlow, Essex: Longman.

Waterford E (2018, August 17) Don't pull the plug on vital ingredient to Sydney's liveability. The Sydney Morning Herald. Retrieved from https://www.smh.com.au/sydney-news/don-tpull-the-plug-on-vital-ingredient-to-sydney-s-liveability-20180816-p4zxxi.html

Wetzstein S (2013) Globalising economic governance, political projects, and spatial imaginaries: Insights from four Australasian cities. Geographical Research 51(1), 71-84.

Williams J (2018, January 25). The number of rough sleepers in Greater Manchester has gone up by 40pc in 12 months. Manchester Evening News. Retrieved from https://www.manchestereveningnews.co.uk/news/greater-manchester-news/number-roughsleepers-greater-manchester-14200603.

World Bank (1996) Livable cities for the 21st century. Directions in development, World Bank Group, Washington, DC. 
Table 1 Examples of liveability discourse

\begin{tabular}{|c|c|}
\hline City or organisation & Conceptualisation of liveability \\
\hline $\begin{array}{l}\text { Hong Kong } \\
\text { Urban development plan: } \\
\text { "Hong Kong 2030" } \\
\text { (Development Bureau and } \\
\text { Planning Department 2007, } \\
\text { p.44) }\end{array}$ & $\begin{array}{l}\text { 'Meant for its residents and must, therefore, be planned to } \\
\text { be liveable, designed to a human scale and reflect the unique } \\
\text { character of a locality' }\end{array}$ \\
\hline $\begin{array}{l}\text { Singapore } \\
\text { Planning framework } \\
\text { (Centre for Liveable Cities } \\
2014, \text { p.6) }\end{array}$ & $\begin{array}{l}\text { 'Three outcomes have been constant in how Singapore } \\
\text { envisioned liveability: A competitive economy in order to } \\
\text { attract investments and provide jobs; a sustainable } \\
\text { environment because the city has to survive with limited } \\
\text { natural resources, especially in terms of land and water; a } \\
\text { high quality of life, including the social and psychological } \\
\text { well-being of the population' }\end{array}$ \\
\hline $\begin{array}{l}\text { Melbourne } \\
\text { Strategic spatial plan: “Plan } \\
\text { Melbourne” (Victoria State } \\
\text { Government, 2017, p.14) }\end{array}$ & $\begin{array}{l}\text { 'We need to ensure the city and suburbs also grow more } \\
\text { liveable. That means we must promote quality design that } \\
\text { focuses on people, environment and cultural identity- } \\
\text { reflecting the past, present and future of Melbourne and } \\
\text { Victoria. Heritage will continue to be one of our greatest } \\
\text { strengths. In particular Aboriginal cultural heritage must be }\end{array}$ \\
\hline
\end{tabular}




\begin{tabular}{|c|c|}
\hline & $\begin{array}{l}\text { recognised and protected as a part of the contemporary and } \\
\text { social life of Melbourne. The city needs to enhance its } \\
\text { reputation as a great place to live and work-and use } \\
\text { liveability as a magnet to attract new people, new ideas and } \\
\text { new opportunities' }\end{array}$ \\
\hline $\begin{array}{l}\text { Auckland } \\
\text { Strategic spatial plan: } \\
\text { "Auckland Plan" (Auckland } \\
\text { Council 2013, p.18) }\end{array}$ & $\begin{array}{l}\text { 'The goal of liveability expresses our shared desire to create } \\
\text { a city where all people can enjoy a high quality of life and } \\
\text { improved standards of living, city which is attractive to } \\
\text { mobile people, firms, and investors, and a place where } \\
\text { environmental and social standards are respected' }\end{array}$ \\
\hline $\begin{array}{l}\text { Vienna } \\
\text { Urban development plan: } \\
\text { "STEP 2025" (City of } \\
\text { Vienna 2014, p.13) }\end{array}$ & $\begin{array}{l}\text { 'Vienna remains a highly liveable and, more specifically, } \\
\text { also a very affordable city - a status that must be preserved } \\
\text { and further developed... Vienna is to remain a liveable city, } \\
\text { where people like to stay, work, study and communicate. The } \\
\text { quality that renders Vienna so attractive is to be experienced } \\
\text { by all-old and young, long-time residents and newcomers } \\
\text { as well as visitors.' }\end{array}$ \\
\hline $\begin{array}{l}\text { UN-Habitat } \\
\text { New Urban Agenda } \\
\text { (UN Habitat 2016, p.29) }\end{array}$ & $\begin{array}{l}\text { 'Leave no one behind, by ending poverty in all its forms and } \\
\text { dimensions, including the eradication of extreme poverty, by } \\
\text { ensuring equal rights and opportunities, socioeconomic and } \\
\text { cultural diversity, and integration in the urban space, by }\end{array}$ \\
\hline
\end{tabular}




\begin{tabular}{|l|l|}
\hline & $\begin{array}{l}\text { enhancing liveability, education, food security and nutrition, } \\
\text { health and well-being' }\end{array}$ \\
\hline $\begin{array}{l}\text { World Bank } \\
\text { the } 21^{\text {st }} \text { century" (World } \\
\text { Bank 1996, p.2) }\end{array}$ & $\begin{array}{l}\text { 'Actions to make cities livable: Bringing basic services to } \\
\text { slums, a healthier urban environment, and finance for } \\
\text { people in cities' }\end{array}$ \\
\hline $\begin{array}{l}\text { OECD } \\
\text { Research report: "How's life } \\
\text { in your region?" (OECD } \\
\text { 2014, p.7) }\end{array}$ & $\begin{array}{l}\text { 'Liveable cities with high-quality infrastructure, green } \\
\text { spand inner city residential areas and public projects } \\
\text { investors as well as highly qualified professionals and } \\
\text { tourists' }\end{array}$ \\
\hline
\end{tabular}


Table 2 Content of urban liveability indices, adapted from Conger (2015), EIU (2015), Giap \& Kaur (2016), International Organization for Standardisation (2014) 


\begin{tabular}{|c|c|c|c|c|c|c|c|}
\hline & Source of index & $\begin{array}{c}\text { EIU Global } \\
\text { Liveability } \\
\text { Ranking }\end{array}$ & $\begin{array}{c}\text { Monocle } \\
\text { Quality of } \\
\text { Life Survey }\end{array}$ & $\begin{array}{c}\text { Mercer } \\
\text { Quality of } \\
\text { Living }\end{array}$ & $\begin{array}{c}\text { PwC } \\
\text { Cities of } \\
\text { Opportunity }\end{array}$ & $\begin{array}{c}\text { Lee Kuan Yew } \\
\text { Global Liveable } \\
\text { Cities Index }\end{array}$ & ISO 37120 \\
\hline Category & Subcategory & Media & Media & Consultant & Consultant & University & Standards Producer \\
\hline \multirow{3}{*}{$\begin{array}{l}\text { Political } \\
\text { environment }\end{array}$} & Terrorism & & & & & & \\
\hline & Political instability & & & & & & \\
\hline & Corruption & & & & & & \\
\hline $\begin{array}{l}\text { Public } \\
\text { services }\end{array}$ & Schools & & & & & & \\
\hline \multirow{4}{*}{$\begin{array}{l}\text { Consumer } \\
\text { goods \& } \\
\text { services }\end{array}$} & Visitor market & & & & & & \\
\hline & $\begin{array}{l}\text { Recreation and } \\
\text { culture }\end{array}$ & & & & & & \\
\hline & Consumer goods & & & & & & \\
\hline & Housing quality & & & & & & \\
\hline \multirow{3}{*}{$\begin{array}{l}\text { Economic } \\
\text { and financial } \\
\text { environment }\end{array}$} & City branding & & & & & & \\
\hline & Living costs & & & & & & \\
\hline & Income inequality & & & & & & \\
\hline \multirow{2}{*}{$\begin{array}{l}\text { Built } \\
\text { environment }\end{array}$} & Architecture design & & & & & & \\
\hline & Infrastructure & & & & & & \\
\hline \multirow{2}{*}{$\begin{array}{l}\text { Natural } \\
\text { environment }\end{array}$} & Comfort and health & & & & & & \\
\hline & Sustainability & & & & & & \\
\hline \multirow{4}{*}{$\begin{array}{l}\text { Social } \\
\text { environment }\end{array}$} & Tolerance & & & & & & \\
\hline & Demographics & & & & & & \\
\hline & Gender equity & & & & & & \\
\hline & Poverty rate & & & & & & \\
\hline
\end{tabular}




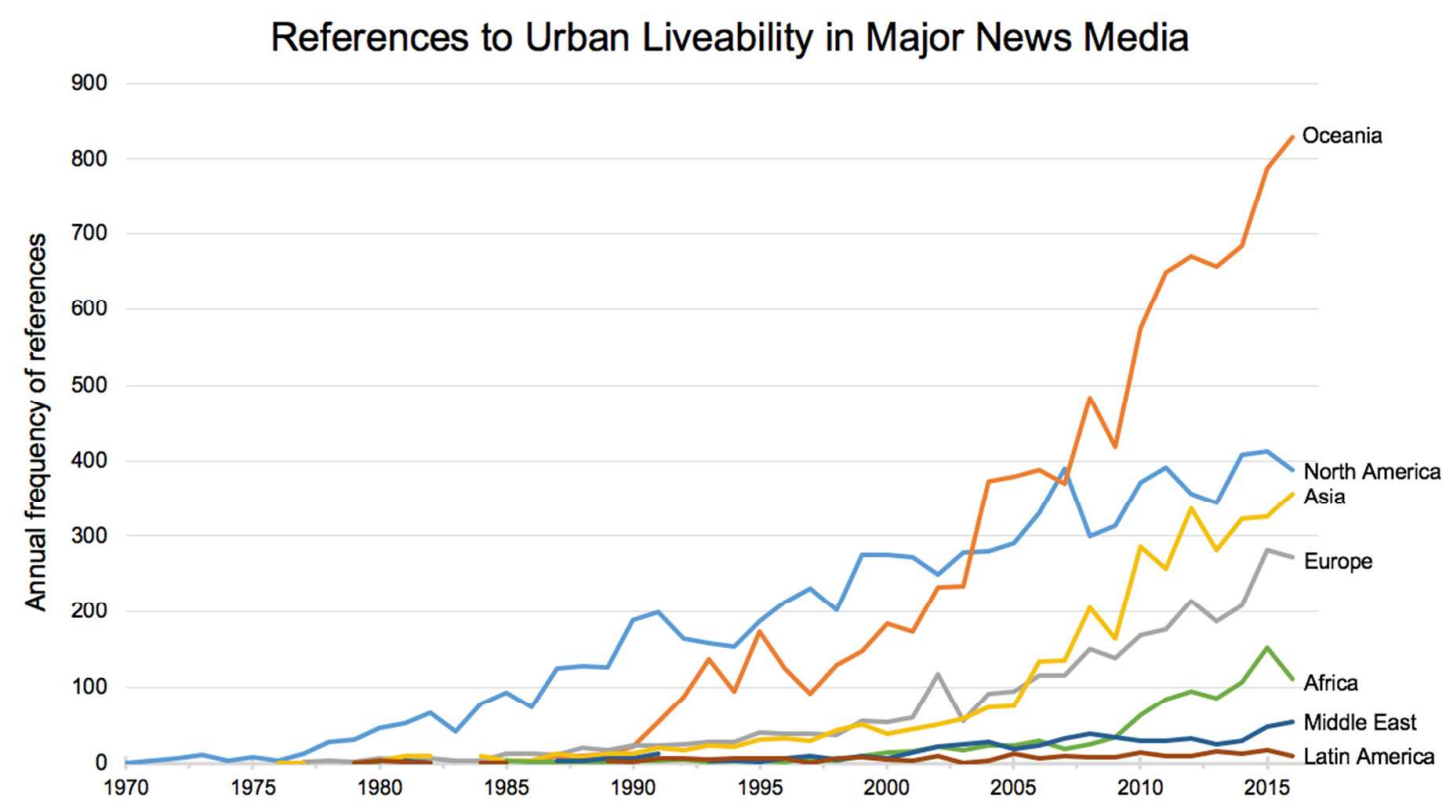

Figure 1 Growth in the frequency of news media related to urban liveability. Source: nexis.com 